\title{
Meningkatkan Hasil Belajar IPA Siswa Melalui Pembelajaran Kooperatif Tipe Time Token Pada Materi Cahaya Di Kelas VIII C Sekolah Menengah Pertama Negeri 7 Batanghari
}

\author{
Desma Yetti \\ Sekolah Menengah Pertama Negeri 7 Batanghari, Indonesia \\ E-mail:desma23@gmail.com
}

\begin{abstract}
The purpose of this study is to improve students' learning result in science studies, especially lighting subject through time token learning model in for students di kelas VIII ${ }^{C}$ SMP $N 7$ Batanghari 2016/2017 academic year. This study employ class action research in three cycles. The data collected through observation, documentation and interview. The subject of this study was students in class VIII ${ }^{\mathrm{C}}$ semester II SMP N 7 Batanghari 2016/2017 academic year. The result of study shows that the time token learning model in science studies is able to improve students learning result in lighting subject. It can be seen from the resultsfrom cycle I to Cycle III (cycle I: 6.50; cycle II: 7.27; cycle III: 8.36 .
\end{abstract}

Keywords: students' learning results, time token model, lighting subject

\section{Pendahuluan}

Salah satu komponen penting dari pendidikan adalah proses belajar mengajar di sekolah. Pada kegiatan belajar dan mengajar ditemukan dua subjek yaitu guru dan siswa. Mengajar bagi seorang guru bukanlah sekedar menyampaikan pengetahuan kepada siswa, tetapi guru dapat memotivasi siswa agar suasana pembelajaran tetap menyenangkan. Hal ini akan berhasil apabila antara guru dan siswa dapat bekerja sama. Menurut Mahpudz guru berperan aktif sebagai fasilitator yang membantu memudahkan siswa dalam pembelajaran dan siswapun dapat mengembangkan pemahaman pengetahuan dan keterampilan sehingga siswa mampu belajar mandiri". (Asep Mahfudz, 2012, p.5) Keberhasilan siswa di sekolah merupakan harapan bagi setiap orang tua, pemerintah dan masyarakat pada umumnya. Keberhasilan pendidikan siswa sangat diharapkan mengingat siswa merupakan generasi yang akan meneruskan pembangunan bangsa di masa yang akan datang. Proses pendidikan yang di laksanakan di sekolah pada intinya adalah pelaksanaan kegiatan belajar mengajar. Melalui proses kegiatan belajar mengajar siswa diharapkan dapat memperoleh prestasi yang setinggi-tingginya sesuai dengan tingkat kemampuannya.

Pembelajaran yang baik adalah pembelajaran yang dapat membuat siswa menjadi tertarik dan termotivasi sehingga pembelajaran yang dilakukan menjadi sangat menyenangkan, yang pada akhirnya akan berpengaruh terhadap hasil belajar siswa itu sendiri. Mata pelajaran IPA di SMP merupakan dasar untuk 
mempelajari IPA pada tingkat berikutnya. untuk mempelajarinya dengan baik diperlukan adanya aktivitas. Aktivitas tersebut dapat berupa perhatian dalam proses belajar mengajar, mengemukakan pendapat, bekerja dalam kelompok dan lain sebagainya. Karena tanpa ada aktivitas yang lengkap, hasil pembelajaran yang diperoleh tidak akan maksimal.

Berdasarkan pengalaman beberapa tahun mengajar di SMPN 7 Batanghari, selama proses belajar IPA, aktivitas siswa dalam belajar sangat kurang sehingga hasil belajar kurang optimal khususnya di kelas VIII ${ }^{\mathrm{C}}$, hal ini terlihat dari kurangnya keterlibatan siswa dalam kegiatan belajar mengajar. Kurangnya aktivitas yang dimaksud adalah keaktivan siswa dalam memperhatikan pelajaran, mengemukakan pendapat dalam rangka menumbuhkan keberanian dan keterampilan siswa dalam mengembangkan pengetahuan dan kurangnya variasi dalam kegiatan pembelajaran.

Setiap kali diadakan kegiatan yang melibatkan aktivitas bersama seperti kerja kelompok, tidak seluruh siswa terlibat dalam kegiatan tersebut. Ada sejumlah siswa yang mendominasi kegiatan kelompok dan siswa lain tidak mau atau tidak dapat berperan serta. Kadang-kadang siswa menghindari kerja kelompok karena malu. Seringkali siswa-siswi yang malu tersebut sangat pandai dan dapat bekerja sendiri dengan baik atau dengan orang lain. Ada juga siswa yang merasa dirinya tersisihkan karena seringkali gugup ketika akan mengeluarkan pendapatnya. Dia merasa nanti teman-teman di kelompoknya akan malu jika dia ikut berbicara. Akhirnya, ada siswa tertentu yang memilih untuk bekerja sendiri dan menolak berperan serta dalam kegiatan-kegiatan kelompok. Meyakinkan agar siswa-siswa malu atau tersisihkan masuk ke dalam kelompok dengan siswa yang memiliki keterampilan sosial yang baik merupakan tanggung jawab seorang guru. Guru memiliki peran yang sangat besar untuk mempengaruhi siswanya agar antusias bekerja dalam kelompok. Dengan menerapkan metode yang tepat guru akan dapat membangkitkan minat siswa untuk bekerja dalam kelompok.

Materi cahaya merupakan materi yang tidak hanya mewajibkan siswanya tahu tentang materi itu saja, tetapi juga memahami konsep dari materi tersebut. Konsep cahaya sulit di cerna oleh siswa jika siswa tidak berperan aktif. Agar siswa dapat memahami konsep tersebut diperlukan metode pembelajaran yang menunjang sehingga konsep tersebut menjadi jelas dan lebih bermakna bagi siswa. Dengan metode kerja kelompok, siswa akan dapat memahami konsep dengan lebih baik.

Salah satu upaya yang ingin diterapkan peneliti untuk mengatasi permasalahan di atas adalah dengan menerapkan Pembelajaran Kooperatif Tipe Time Token. Tipe ini baik digunakan untuk meningkatkan peran serta siswa dalam kelompok. Time Token akan membantu siswa yang tidak dapat berperan serta dalam kegiatan kelompok. Siswa tidak akan dapat mendominasi percakapan karena diberikan waktu yang sama untuk berbicara.

Dengan adanya keterlibatan siswa dalam kegiatan pembelajaran, maka diharapkan mereka akan lebih banyak belajar dan meningkatkan kepercayaan diri saat mengungkapkan pengetahuannya dihadapan guru dan teman-temannya, sehingga menimbulkan suasana pembelajaran yang menyenangkan, dan 
menambah daya ingat siswa terhadap pelajaran yang dipelajari, karena mereka mengalami sendiri proses pembelajarannya.

Penelitian ini bertujuan untuk meningkatkan hasil belajar IPA siswa melalui pembelajaran kooperatif tipe time token pada materi cahaya dikelas VIII ${ }^{\mathrm{C}}$ SMP N 7 Batanghari.

\section{Belajar}

Menurut Rusman belajar adalah perubahan tingkah laku individu sebagai hasil dari pengalamannya dalam berinteraksi dengan lingkungannya. (Rusman, 2012, p.134) Jadi seseorang yang telah menjalani suatu proses yang disebut belajar tersebut hendaknya mampu merubah dirinya baik dari sikap maupun kemampuan intelektualnya kearah yang lebih baik sehingga dapat memberi manfaat untuk dirinya maupun orang lain.

Menurut Sardiman belajar merupakan perubahan tingkah laku atau penampilan dengan serangkaian kegiatan misalnya, membaca, mengamati, mendengarkan, meniru dan lain sebagainya. (A Sardiman, 2001, p.20) Berdasarkan pengertian tersebut dapat disimpulkan bahwa belajar adalah suatu proses usaha yang dilakukan seorang baik sengaja maupun tidak sengaja oleh seseorang sebagai hasil pengalamannya, untuk memperoleh perubahan tingkah laku yang baru baik secara keseluruhan, sehingga terdapat perubahan dalam hal pengetahuan, pemahaman, keterampilan, dan nilai sikap pada diri individu tersebut.

Belajar dipengaruhi oleh beberapa faktor sepertibahan yang dipelajari, faktor instrumental, lingkungan, dan kondisi individual si pelajar. Belajar itu selalu melibatkan tiga hal pokok yaitu: adanya perubahan tingkah laku, sifat perubahannya relatif permanen, serta perubahan tersebut disebabkan oleh interaksi dengan lingkungan, bukan oleh perubahan-perubahan kondisi fisik yang sifatnya sementara. Proses belajar tidak hanya terjadi karena adanya interaksi antara siswa dengan guru.

\section{Hasil Belajar}

Hamalik menyatakan bahwa hasil belajar tampak sebagai terjadinya perubahan tingkah laku pada diri siswa yang dapat diamati dan diukur dalam bentuk perubahan pengetahuan, sikap dan keterampilan. (Oemar Hamalik, 2002, p.155) Perubahan tersebut dapat diartikan terjadinya peningkatan dan pengembangan yang lebih baik dibandingkan dengan sebelumnya, misalnya dari tidak tahu menjadi tahu, sikap kurang sopan menjadi sopan, dan sebagainya”.

Pendidikan dan pengajaran dikatakan berhasil apabila perubahan-perubahan yang terlihat pada diri siswa merupakan akibat dari proses belajar yang dialaminya. Setidaknya apa yang dicapai oleh siswa merupakan proses yang ditempuhnya melalui program dan kegiatan yang dirancang dan dilaksanakan oleh guru dalam proses mengajarnya.

Hasil belajar melingkup tiga ranah, yakni ranah kognitif, ranah afektif dan ranah psikomotorik. Ketiga ranah tersebut saling berhubungan satu sama lain, jadi satu ranah tidak dapat berdiri sendiri dalam proses pembelajaran, tapi ranah kognitif kadang lebih dominan dibandingkan kedua ranah yang lain. Pertimbangan guru lebih mengutamakan ranah kognitif, karena penilaian ranah kognitif dianggap lebih mudah dibanding yang lain, tetapi bukan berarti ranah 
yang lain diabaikan. Dalam penilaian ranah kognitif lebih mudah dilakukan karena hasilnya bisa diketahui dengan penilaian tes, sedangkan ranah afektif dan ranah psikomotorik dapat diketahui hasilnya dengan penlaian non tes.

\section{Pembelajaran IPA}

Pembelajaran IPA adalah pembelajaran yang menekankan pada pengembangan keterampilan berpikir melalui proses dan produk. Menurut Noeraida, IPA merupakan ilmu yang diperoleh dan di kembangkan berdasarkan percobaan (induktif), namun pada perkembangan selanjutnya IPA juga diperoleh dan di kembangkan berdasarkan teori (deduktif). (Noeraida, dkk, 2016, p.5) Ada dua hal yang berkaitan dengan IPA yang tidak terpisahkan, yaitu IPA sebagai produk (pengetahuan IPA yang berupa fakta, konsep, prinsip, hukum, dan teori) temuan ilmuwan dan IPA sebagai proses (kerja ilmiah). Oleh sebab itu, pembelajaran IPA dan penilaian hasil belajar IPA harus memperhatikan karakteristik ilmu IPA sebagai proses dan produk.

\section{Model Pembelajaran}

Menurut Trianto model pembelajaran adalah suatu perencanaan atau pola yang dapat digunakan oleh pengajar atau guru untuk mendesain pola-pola melalui model pembelajaran guru dapat membantu peserta didik mendapatkan informasi, ide, keterampilan, cara berfikir, dan mengekspresikan ide. (Trianto, 2010, p. 52) Model pembelajaran berfungsi pula sebagai pedoman bagi para perancang pembelajaran dan para guru dalam merencanakan aktivitas belajar mengajar.

\section{Pembelajaran Kooperatif}

Salah satu pembelajaran yang melibatkan diri siswa keseluruhan adalah bentuk pembelajaran kooperatif. Pembelajaran kooperatif merupakan bentuk pembelajaran kelompok, dimana siswa bekerjasama dengan anggota kelompoknya untuk mempelajari suatu materi pelajaran. Seperti yang dijelaskan oleh Sudibyo dalam Hartati pembelajaran kooperatif adalah model pengajaran dimana siswa belajar dalam kelompok-kelompok kecil yang memiliki kemampuan berbeda. (Hartati, 2006, p.8) Sedangkan menurut Anam dalam Hartati pembelajaran kooperatif adalah kegiatan belajar mengajar secara kelompok-kelompok kecil; siswa belajar dan bekerjasama untuk sampai pada pengalaman yang optimal baik pengalaman individu maupun kelompok. (Hartati, 2006, p.8) Dalam menyelesaikan tugas kelompok setiap anggota saling bekerjasama dan membantu untuk memahami suatu bahan pebelajaran. Belajar belum selesai jika salah satu teman dalam kelompok belum menguasai bahan pembelajaran.

Menurut Suparman dalam Hartati, pembelajaran kooperatif adalah model pembelajaran yang sistematis dengan mengelompokkkan siswa dengan tujuan menciptakan pendekatan pembelajaran yang efektif yang mengintegrasikan keterampilan sosial yang bermuatan akademis. (Hartati, 2006, p.9) Dari pengertian yang terakhir ini, maka dalam pembelajaran kooperatif akan diusahakan untuk mengembangkan keterampilan sosial yang bermuatan akademis yang sesuai dengan landasan bentuk dari pembelajaran kooperatif.

Menurut Hartati pembelajaran kooperatif memiliki 5 prinsip dasar yang menguntungkan, yaitu: (Hartati, 2006, p.9) 
a. Saling ketergantungan yang positif

Anggota kelompok siswa harus mengatakan bahwa mereka memerlukan kerjasama untuk mencapai tujuan kelompok.

b. Interaksi berhadap-hadapan (face to face)

Kelompok kecil yang terdiri dari 4 sampai 5 anggota, saling bekerjasama untuk mendapatkan hasil belajar yang lebih baik dimana setiap anggota duduk berhadapan.

c. Kemampuan kelompok secara individu

Semua anggota kelompok harus mempunyai kemampuan menanggapi suatu masalah dan mengembangkan ide-idenya untuk keberhasilan kelompok.

d. Menggunakan keterampilan sosial

Beberapa siswa memiliki kekurangan dalam ketrampilan sosial, sementara itu siswa membutuhkan waktu untuk belajar. Dalam hal ini guru harus menjelaskan dasar-dasar keterampilan sosial sebelum pelajaran dimulai. Guru harus memfokuskan satu keterampilan setiap minggu, mencatat dengan pasti perilaku kooperatif dan membuat umpan balik untuk kelompok.

e. Proses kelompok

Siswa harus mengevaluasi efektivitas kelompok mereka saat kerja kelompok. Kelompok perlu mempertahankan keberhasilannya dan mampu memperbaiki kekurangannya, hal ini menolong siswa untuk memecahkan masalah.

\section{Proses Pembelajaran Kooperatif}

Pembelajaran kooperatif menuntut peran guru yang relatif berbeda dari pembelajaran yang biasa dilakukan. Adapun proses pembelajaran kooperatif menurut Ema dalam Fitriani sebagai berikut: (Fitriani, 2005, p.10)

a. Merumuskan tujuan pembelajaran

b. Menentukan jumlah anggota tiap-tiap kelompok belajar

c. Menempatkan anak dalam kelompok

d. Merancang bahan untuk meningkatkan saling ketergantungan

e. Menentukan peran anak untuk menunjang saling ketergantungan

f. Menjelaskan tugas akademik

g. Menyusun kerjasama antar kelompok

h. Menjelaskan prilaku yang diharapkan

i. Memantau prilaku anak.

j. Memberikan bantuan dalam menyelesaikan tugas

k. Melakukan intervensi untuk mengajarkan ketrampilan bersama

1. Menutup pelajaran.

\section{Unsur-Unsur Dasar dan Ciri-ciri Pembelajaran Kooperatif}

Menurut Rusman unsur-unsur dasar pembelajaran kooperatif adalah sebagai berikut: (Rusman, 2012, p.208)

a. Siswa dalam kelompoknya harus beranggapan bahwa mereka "sehidup sepenanggungan bersama".

b. Siswa bertanggung jawab atas segala sesuatu didalam kelompoknya, seperti milik mereka sendiri. 
c. Siswa haruslah melihat bahwa semua anggota di dalam kelompoknya memiliki tujuan yang sama.

d. Siswa haruslah membagi tugas dan tanggung jawab yang sama diantara anggota kelompoknya.

e. Siswa akan dikenakan evaluasi atau diberikan hadiah / penghargaan yang juga akan dikenakan untuk semua anggota kelompok

f. Siswa berbagi kepemimpinan dan mereka membutuhkan ketrampilan untuk belajar bersama selama proses belajarnya.

g. Siswa akan diminta bertanggung jawabkan secara individual materi yang ditangani dalam kelompok kooperatif.

Adapun ciri-ciri umum pembelajaran kooperatif menurut Ibrahim, M (2000:6) sebagai berikut :

a. Siswa bekerja dalam kelompok secara kooperatif untuk menuntaskan materi belajarnya.

b. Kelompok dibentuk dari siswa yng memiliki kemampuan tinggi, sedang, dan rendah.

c. Bilamana mungkin, anggota kelompok berasal dari ras, budaya, suku, jenis kelamin yang berbeda-beda.

d. Penghargaan lebih berorientasi kepada kelompok ketimbang individu.

\section{Langkah-Langkah Pembelajaran Kooperatif}

Menurut Ibrahim dalam pembelajaran kooperatif terdapat enam langkah pada setiap pembelajaran. (M Ibrahim, dkk, 2000, p.10) Keenam langkah yang dimaksud adalah seperti yang terdapat didalam tabel langkah-langkah pembelajaran kooperatif dibawah ini: 
Tabel 1. Langkah-Langkah Pembelajaran Kooperatif

\begin{tabular}{|c|c|}
\hline Fase & Tingkah laku Guru \\
\hline $\begin{array}{l}\text { Fase-1 } \\
\begin{array}{l}\text { Menyampaikan tujuan dan } \\
\text { memotivasi siswa }\end{array}\end{array}$ & $\begin{array}{l}\text { Guru menyampaikan semua tujuan } \\
\text { pelajaran yang ingin dicapai pada } \\
\text { pembelajaran tersebut dan memotivasi } \\
\text { siswa belajar }\end{array}$ \\
\hline $\begin{array}{l}\text { Fase- } 2 \\
\text { Menyajikan informasi }\end{array}$ & $\begin{array}{l}\text { Guru menyajikan informasi kepada siswa } \\
\text { dengan jalan demonstrasi atau lewat } \\
\text { bahan bacaan }\end{array}$ \\
\hline $\begin{array}{l}\text { Fase }-3 \\
\text { Mengorganisasikan }\end{array}$ & $\begin{array}{l}\text { Guru menjelaskan kepada siswa } \\
\text { bagaimana caranya membentuk kelompok }\end{array}$ \\
\hline $\begin{array}{l}\text { kedalam kelompok-kelompok } \\
\text { belajar }\end{array}$ & $\begin{array}{l}\text { belajar dan membantu setiap kelompok } \\
\text { agar melakukan transisi secara efesien } \\
\text { Guru membimbing kelompok-kelompok } \\
\text { belajar pada saat mereka mengerjakan } \\
\text { tugas mereka }\end{array}$ \\
\hline $\begin{array}{l}\text { Membimbing kelompok bekerja } \\
\text { dan belajar } \\
\text { Fase-5 } \\
\text { Evaluasi }\end{array}$ & $\begin{array}{l}\text { Guru mengevaluasi hasil belajar tentang } \\
\text { materi yang telah dipelajari atau masing- } \\
\text { masing kelompok mempresentasikan hasil } \\
\text { kerjanya } \\
\text { Guru mencari cara-cara untuk menghargai } \\
\text { baik upaya maupun hasil belajar individu } \\
\text { dan kelompok }\end{array}$ \\
\hline
\end{tabular}

\section{Pengertian Pembelajaran Time Token}

Untuk mengajarkan dan menjamin peran serta yang seimbang antara anggota kelompok, time token merupakan kegiatan khusus yang mengajarkan ketrampilan berperan serta. Menurut pendapat Benyamin Bloom dalam Fitrini ada tiga ide untuk berdiskusi salah satunya adalah "Time Tokens- give out tokens each worth a specific amount of time. Once they've cashed in their tokens, they' are done talking”. (Fitriani, 2005, p.13) Maksud dari kutipan diatas adalah bahwa time token merupakan kegiatan dengan memberikan batasan waktu khusus untuk sebuah pendapat. Bila mereka telah sampai pada apa yang dibicarakan batasi dia untuk tidak berbicara lagi dengan menggunakan kartu.

Sejalan dengan itu Ibrahim. dalam Fitriani mengatakan bahwa, "time token adalah suatu kegiatan khusus yang dilakukan oleh seorang guru dalam pembelajaran kooperatif dengan menggunakan kartu-kartu untuk berbicara. Time token dapat membantu peran serta lebih merata pada setiap siswa". (Fitriani, 2005, p.10)

Menurut Arends dalam Fitriani "tujuan dalam pembelajaran kooperatif tipe Time Token adalah untuk melatih dan mengembangkan keterampilan sosial terutama keterampilan berkomunikasi agar siswa tidak mendominasi pembicaraan atau diam sama sekali dimana siswa dituntut aktif dan berpartisipasi, dengan adanya kupon dan batas waktu yang ditentukan agar dapat mengembangkan inisiatifnya dalam proses pembelajaran". (Fitriani, 2005, p.29) Selanjutnya 
Arrends dalam Fitriani mengemukakan time token yaitu guru memberikan batasan waktu kepada siswa untuk menanggapi jawaban dari permasalahan yang telah diberikan dengan menggunakan kartu-kartu berbicara yaitu sekitar \pm 30 detik. Seorang siswa memonitor interaksi dan meminta siswa-siswa (pembicara) untuk berhenti jika melebihi batas waktu yang telah ditentukan. (Fitriani, 2005, p.14)

\section{Ciri-ciri Pembelajaran Time Token}

Ciri-ciri time token menurut pendapat Ibrahim dalam Fitriani yaitu: (Fitriani, 2005, p.14)

1. Masing-masing siswa diberikan kartu untuk berbicara

2. Seorang siswa menjadi pemonitor

3. Kartu berbicara nilainya 30 detik

4. Kartu harus diserahkan kepada pemonitor jika selesai berbicara mengenai suatu masalah.

\section{Proses Pembelajaran Time Token}

Time token merupakan suatu variasi dalam pembelajaran kooperatif yang dirancang untuk mempengaruhi pola interaksi siswa. Tipe ini dilaksanakan untuk membagikan peran serta siswa dalam kelompok, karena tidak semua siswa mau dan dapat berperan serta dalam kegiatan kelompok.

Pembelajaran time token digunakan untuk meningkatkan keterampilan berperan siswa dalam kelompok. Time token dapat dilaksanakan jika guru sudah memiliki kelompok-kelompok pembelajaran, tetapi tidak semua siswa dapat berperan serta dalam kegiatan kelompok. Pembelajaran ini efektif untuk kelas yang didalamnya terdapat kesenjangan dalam hal kemampuan berbicara. Artinya ada siswa yang mendominasi pembicaraan dikelas dan sebaliknya ada yang pasif.

Langkah-langkah dalam pembelajaran Time Token menurut Aqib adalah: (Zainal Aqib, 2013, p.33)

1. Kondisikan siswa untuk melaksanakan diskusi (Cooperative Learning/CL).

2. Tiap siswa diberi kupon berbicara dengan waktu \pm 30 detik.

3. Tiap siswa diberi sejumlah nilai sesuai waktu keadaan.

4. Jika telah selesai bicara, kupon yang dipegang siswa diserahkan. setiap berbicara satu kupon.

5. Siswa yang telah habis kuponnya tidak boleh bicara lagi, sedangkan yang masih memegang kuponnya, harus bicara sampai kuponnya habis.

Langkah-langkah pembelajar ini ditegaskan lagi oleh Ibrahim, yaitu: (1) setiap siswa diberikan beberapa kupon berbicara dengan nilai 30 detik waktu berbicara, (2). Seorang siswa memonitor interaksi dan meminta pembicara untuk menyerahkan satu kupon apabila ia telah menghabiskan waktu yang ditetapkan oleh kupon itu. (M Ibrahim, dkk, 2000, p.14)

Dengan demikian langkah-langkah pembelajaran time token adalah:

1. Mempersiapkan sejumlah kupon (kartu kecil)

2. Membagikan kupon berbicara kepada setiap siswa dengan niai 30 detik berbicara yang sama banyaknya (2-3 kartu)

3. Menyampaikan materi seperti biasa, baik dengan cara demonstrasi maupun lewat bahan bacaan.

4. Menunjuk pemonitor dalam kelompok. 
5. Pemonitor yang telah ditunjuk meminta pembicara untuk meyampaikan pendapatnya mengenai masalah yang diberikan dan harus menyerahkan satu kupon apabila ia telah menghabiskan waktu yang ditetapkan didalam kuponnya, siswa itu tidak dapat berbicara lagi. Sedangkan siswa yang masih memegang kupon harus berbicara sampai kuponya habis. Hal ini akan memacu semangat siswa yang masih memegang kupon untuk berbicara.

Berdasarkan uraian di atas, pembelajaran kooperatif time token mempunyai kelebihan sebagai berikut:

a. Semua anggota kelompok terlibat aktif dalam diskusi kelompok.

b. Mendorong siswa untuk meningkatkan inisiatif dan partisipasinya.

c. Siswa tidak mendominasi pembicaraan atau diam saja.

d. Setiap siswa merasa dihargai karena memiliki waktu yang sama dalam memberikan ide, pendapat maupun masukan mengenai suatu masalah.

e. Tidak memerlukan banyak media pembelajaran.

Selain mempunyai kelebihan pembelajaran kooperatif time token juga mempunyai kelemahan yaitu akan memakan waktu yang lama jika harus menunggu siswa yang pemalu untuk berbicara.

\section{Pengertian Cahaya}

Cahaya merupakan salah satu bentuk energi yang dipancarkan oleh benda atau sumber cahaya dalam bentuk gelombang elektromagnetik. Gelombang elektromagnetik tidak memerlukan medium dalam perambatannya, sehingga dapat merambat dalam ruang hampa (vakum). Cepat rambat cahaya sama dengan cepat rambat gelombang elektromagnetik, yaitu $3.10^{8} \mathrm{~m} / \mathrm{s}$. Cahaya akan memancar kesegala arah dan merambat lurus apabila cahaya itu merambat melalui medium yang sama.

\section{Pemantulan Cahaya}

Salah satu sifat cahaya yaitu akan dipantulkan jika menembus dinding penghalang. Ada dua macam pemantulan cahaya yaitu pemantulan teratur dan pemantulan tidak teratur (baur). Pemantulan baur terjadi jika cahaya jatuh pada permukaan benda yang kasar, maka sinar dipantulkan ke berbagai arah, maka sinar pantul berpotongan setelah meninggalkan permukaan. Sedangkan pemantulan teratur terjadi pada permukaan benda yang halus atau rata.

Hukum pemantulan cahaya:

a. Sinar datang, garis normal dan sinar pantul terletak pada satu bidang datar.

b. Besar sudut datang sama dengan besar sudut pantul

\section{Pemantulan Pada Cermin Datar}

Cermin datar adalah sebuah cermin yang permukaan pantulnya berupa bidang datar.

Sifat - sifat cermin datar:
a. Jarak bayangan ke cermin $\left(\mathrm{s}^{1}\right)=$ jarak benda ke cermin (s).
b. Tinggi bayangan $\left(\mathrm{h}^{1}\right)=$ tinggi benda $(\mathrm{h})$
c. Posisi bayangan = posisi benda
d. Bayangan bersifat maya karena berada dibelakang cermin.
e. Bayangan selalu bertukar sisi dengan bendanya. 
Jika dua buah cermin datar membentuk sudut satu sama lain, maka jumlah bayangan yang dibentuk adalah $: \mathrm{n}=\frac{360}{\alpha}-1$

\section{Pemantulan Pada Cermin Cekung}

Cermin cekung bersifat konvergen atau mengumpulkan sinar, Cermin cekung dapat digunakan sebagai cermin cukur, lampu mobil, lampu sorot dan lain-lain.

Sinar-sinar istimewa pada cermin cekung :

a. Sinar datang sejajar dengan sumbu utama dipantulkan melalui fokus.

b. Sinar datang melalui titik pusat dipantulkan kembali melalui titik pusat.

c. Sinar datang melalui fokus dipantulkan sejajar dengan sumbu utama.

\section{Pemantulan Pada Cermin Cembung}

Cermin cembung bersifat divergen atau menyebarkan sinar. Cermin cembung digunakan dalam kaca spion mobil.

Sinar-sinar istimewa pada cermin cembung:

a. Sinar datang sejajar dengan sumbu utama dipantulkan seolah-oleh dari fokus.

b. Sinar datang yang menuju titik pusat kelengkungan cermin dipantulkan melalui titik pusat.

c. Sinar datang melalui fokus dipantulkan sejajar sumbu utama.

\section{Bagian-Bagian Cermin Cekung dan Cembung}

$$
\begin{aligned}
& \mathrm{SU}=\text { sumbu utama } \\
& \mathrm{P}=\text { titik pusat kelengkungan } \\
& \mathrm{R}=\text { jari-jari kelengkungan } \\
& \mathrm{O}=\text { titik pusat cermin } \\
& \mathrm{F}=\text { titik fokus }
\end{aligned}
$$

Hubungan $s, s^{1}, h$ dan $h^{1}$.

$$
\frac{1}{f}=\frac{1}{s}+\frac{1}{s^{1}}
$$

Perbesaran bayangan : $\mathrm{M}=\left|\frac{h^{1}}{h}\right|=\left|\frac{s^{1}}{s}\right|$

Keterangan : $\quad \mathrm{s}=$ Jarak benda kecermin

$\mathrm{s}^{1}=$ Jarak bayangan kecermin

$\mathrm{f}=$ Jarak fokus ke cermin

$\mathrm{h}=$ Tinggi benda

$\mathrm{h}^{1}=$ Tinggi bayangan

$\mathrm{M}=$ Perbesaran

\section{Pembiasan Cahaya}

Pembiasan adalah peristiwa pembelokan cahaya karena merambat melalui dua medium yang berbeda kerapatan optiknya.

\section{Hukum Snellius}

a. Sinar datang, garis normal dan sinar bias terletak pada satu bidang datar.

b. Perbandingan sinus sudut datang (i) dan sinus sudut bias (r) merupakan konstanta (tetap).

\section{Indeks Bias}


Menurut Snellius, perbandingan sinus sudut datang (i) dan sinus sudut bias (r) adalah bilangan tetap yang disebut indeks bias (n).

Sehingga dapat dirumuskan: $\mathrm{n}_{21}=\frac{\sin i}{\sin r}=\frac{v_{1}}{v_{2}}$

Keterangan :

$$
\begin{array}{ll}
\mathrm{n}_{21} & =\text { indeks bias medium } 2 \text { terhadap medium } 1 \\
\sin \mathrm{i} & =\text { sudut datang } \\
\sin \mathrm{r} & =\text { sudut bias } \\
\mathrm{v}_{1} & =\text { cepat rambat cahaya medium } 1(\mathrm{~m} / \mathrm{s}) \\
\mathrm{v}_{2} & =\text { cepat rambat cahaya medium } 2(\mathrm{~m} / \mathrm{s})
\end{array}
$$

Perbandingan kecepatan cahaya diruang hampa udara dengan kecepatan cahaya dalam suatu medium disebut indeks bias medium $\left(\mathrm{n}_{\text {medium }}\right)$ dan dirumuskan sebagai berikut :

$$
\mathrm{n}_{\text {medium }}=\frac{c}{v} \text {. }
$$

Keterangan: $\mathrm{c}=$ kecepatan rambat cahaya diruang hampa udara $\left(3.10^{8} \mathrm{~m} / \mathrm{s}\right)$

\section{Pembiasan Pada Lensa}

$\mathrm{v}=$ kecepatan cahaya dalam medium

$\mathrm{n}=$ indeks bias medium

Lensa adalah benda bening yang dibatasai oleh dua bidang lengkung atau sebuah bidang lengkung dan sebuah bidang datar. Ada 2 jenis lensa yaitu lensa cembung dan lensa cekung.

\section{Pembiasan Pada Lensa Cembung.}

Lensa cembung bersifat konvergen atau mengumpulkan cahaya. 3 macam lensa cembung :

a. Lensa cembung rangkap (bikonveks)

b. Lensa cembung datar (plankonveks)

c. Lensa cembung cekung (konkaf-konveks)

Sinar-sinar istimewa pada lensa cembung:

a. Sinar datang sejajar sumbu utama dibiaskan melalui fokus.

b. Sinar datang melaui fokus dibiaskan sejajar dengan sumbu utama.

c. Sinar datang menuju titik pusat dibiaskan kembali melalui titik pusat.

\section{Pembiasan Pada Lensa Cekung} cekung:

Lensa cekung bersifat divergen atau menyebarkan cahaya. 3 macam lensa

a. Lensa cekung rangkap (bikonkaf)

b. Lensa cebung datar (plankonkaf)

c. Lensa cembung cekung (konveks-konkaf)

Sinar-sinar istimewa pada lensa cekung :

a. Sinar datang sejajar sumbu utama dibiaskan seolah-olah dari fokus.

b. Sinar datang melalui fokus dibiaskan sejajar sumbu utama.

c. Sinar datang melalui pusat optik diteruskan.

\section{Bagian-Bagian Lensa Cembung Dan Cekung}

$\mathrm{F}_{1} \quad=$ titik fokus maya (pasif) dan terletak di depan lensa

$\mathrm{F}_{2} \quad=$ titik fokus sejati (aktif)

$\mathrm{SU}=$ sumbu utama

$\mathrm{O}=$ titik pusat lensa 
$\begin{array}{cc}\mathrm{R} & =\text { jari-jari ke } \\ \text { Hubungan } \mathbf{s}, \mathbf{s}^{\mathbf{1}} \text {, } \mathbf{h} \text { dan } \mathbf{h}^{\mathbf{1}} \text {. }\end{array}$

$$
\frac{1}{f}=\frac{1}{s}+\frac{1}{s^{1}} \quad \text { karena } \mathrm{R}=2 \mathrm{f} \text { maka } \frac{2}{R}=\frac{1}{s}+\frac{1}{s^{1}}
$$

Perbesaran bayangan : $\mathrm{M}=\left|\frac{h^{1}}{h}\right|=\left|\frac{s^{1}}{s}\right|$

Keterangan: $\mathrm{s}=$ jarak benda

$$
\begin{aligned}
& \mathrm{s}^{1}=\text { jarak bayangan } \\
& \mathrm{f}=\text { jarak focus lensa } \\
& \mathrm{h}=\text { tinggi benda } \\
& \mathrm{h}^{1}=\text { tinggi bayangan } \\
& \mathrm{M}=\text { pembesaran } \\
& \mathrm{R}=\text { jari-jari kelngkungan lensa. }
\end{aligned}
$$

\section{Metode}

Sesuai dengan masalah yang telah dikemukakan sebelumnya, maka jenis penelitian ini adalah Penelitian Tindakan Kelas (Classroom Action Research) yang direncanakan sebanyak tiga siklus dengan tahapan-tahapan pelaksanaan meliputi:Perencanaan, Pelaksanaan tindakan, Observasi dan Refleksi. Penelitian tindakan kelas ini dilaksanakan di kelas VIII ${ }^{\mathrm{C}}$ semester II SMP N 7 Batanghari tahun ajaran 2016/2017.

Penelitian ini dilakukan pada siswa kelas VIII ${ }^{\mathrm{C}}$ semester II SMP Negeri 7 Batanghari tahun ajaran 2016/2017 yang berjumlah 22 siswa yang terdiri dari 11 siswa laki-laki dan 11 siswa perempuan. Jenis data yang diambil dalam penelitian ini berupa data kuantitatif yaitu data tentang hasil belajar siswa setiap akhir siklus, tentang hasil siswa belajar diambil melalui tes ulangan (formatif) yang dilakukan setiap akhir siklus pelajaran dan data kualitatif yaitu data tentang aktivitas siswa dan aktivitas guru dalam belajar mengajar. Pengambilan data kualitatif dilakukan dengan menggunakan lembar pengamatan aktivitas siswa dan lembar pengamatan aktivitas guru selama kegiatan belajar mengajar berlangsung.

Penelitian ini dilaksanaka dalam tiga siklus yang terdiri dari siklus I, siklus II dan siklus III. Pada setiap siklus memiliki tahapan-tahapan tertentu sesuai dengan tahapan dalam tindakan kelas yang dikemukakan oleh Arikunto (2012:12). Tahapan-tahapan yang dimaksud adalah: 1). Perencanaan, 2). Pelaksanaan, 3). Observasi (pengamatan), 4). Refleksi.Penelitian terhadap hasil observasi mengenai aktivitas belajar siswa di hitung menggunakan rumus:

$$
\begin{aligned}
& \mathrm{PSA}=\frac{N a}{N} \times 100 \% \quad \text { Sudjana }(1996: 67) \\
& \text { Keterangan: PSA }=\text { Persentase siswa yang aktif } \\
& \mathrm{Na} \quad=\text { Jumlah siswa yang aktif } \\
& \mathrm{N}=\text { Jumlah siswa keseluruhan } \\
& 21-40 \%=\text { Kurang aktif } \\
& 41-60 \%=\text { Cukup aktif } \\
& 61-80 \%=\text { Aktif } \\
& 81-100 \%=\text { Sangat aktif }
\end{aligned}
$$

Sedangkan proses perhitungan data hasil belajar siswa di peroleh dari hasil pemberian tes pada tahap evaluasi. 


\section{Indikator Keberhasilan}

Indikator keberhasilan penelitian ini adalah:

1. Meningkatnya nilai hasil belajar siswa pada kategori tuntas di atas KKM $(7,5)$ minimal $70 \%$.

2. Aktivitas pelaksanaan skenario pembelajaran oleh guru mencapai minimal $70 \%$ dan meningkatnya aktivitas siswa setiap indicator

\section{Hasil} pengamatan.

Siklus I dilaksanakan tanggal 7, 8 dan 10 Maret 2017. Siklus II dilaksanakan tanggal 14, 15 dan 17 Maret 2017. Siklus III di laksanakan tanggal 21, 22 dan 25 Maret 2017.

\section{Siklus I}

\section{Perencanaan}

Pada tahap perencanaan, peneliti mempersiapkan perangkat pembelajaran, seperti RPP, LKS, alat dan bahan praktikum, kupon (kartu kecil), serta soal tes siklus I.

\section{Pelaksanaan Tindakan}

Pelaksanaan tidakan pada siklus 1 dibagi dalam 3 kali pertemuan, pertemuan pertama mengenai sub materi perambatan cahaya dan pertemuan kedua mengenai pemantulan cahaya dengan praktikum pemantulan pada cermin datar. Langkah-langkah tindakan pada siklus 1 ini sesuai dengan rencana pelaksanaan pembelajaran 1 dan rencana pelasanaan pembelajaran 2. Pelaksanaan pembelajaran dengan menggunakan pembelajaran kooperatif lebih ditekankan dengan usaha mengembangkan keterampilan siswa dalam menyampaikan pendapatnya dalam diskusi. Diawal pelajaran, pengenalan dilakukan dengan menjelaskan tata cara pembelajaran kooperatif tipe time token dan materi perambatan cahaya serta menyampaikan tujuan pembelajaran kepada siswa.Pada pertemuan terakhir pada siklus 1, siswa diberikan tes yang akan diadakan dalam bentuk tes formatif 1 . Hal ini untuk mengetahui penguasaan siswa pada materi yang telah diajarkan. Tes ini terdiri dari 10 soal pilihan ganda.

\section{Hasil Belajar}

Setelah pelaksanaan tindakan pada siklus 1 berlangsung, maka diadakan ulangan formatif 1 . Hasil yang diperoleh siswa dari tes formatif 1 dapat dilihat pada tabel berikut:

Tabel 3. Hasil Belajar Siklus 1 yang Diikuti oleh 22 Orang Siswa.

\begin{tabular}{|c|l|c|}
\hline No & \multicolumn{1}{|c|}{ Variabel yang diamati } & Jumlah / Persentase \\
\hline 1 & Nilai rata-rata siswa & $6,50(65,0 \%)$ \\
2 & Jumlah siswa yang berhasil & 9 Orang \\
\hline
\end{tabular}

Dari tabel diketahui bahwa nilai rata-rata siswa masih rendah. Hal ini terlihat dari rendahnya nilai rata-rata yang diperoleh siswa pada siklus I yaitu 6,50. Dan jumlah siswa memperoleh nilai $\geq 7,5$ hanya 9 orang atau $40,9 \%$ dari jumlah siswa secara keseluruhan, artinya tindakan yang diberikan pada siklus I belum dapat meningkatkan hasil belajar siswa.

\section{Hasil Observasi}


Berdasarkan hasil observasi yang merupakan gambaran aktivitas siswa selama proses pembelajaran berlangsung. Secara keseluruhan aktivitas siswa bekerja dalam kelompok belum berlangsung secara optimal. Aktivitas siswa yang diamati belum sesuai dengan yang diharapkan, masih ada kategori nilai cukup dan kurang untuk beberapa aktivitas. Hal ini menunjukkan beberapa kekurangan antara lain:

1. Perhatian siswa waktu guru menjelaskan materi pelajaran kurang.

2. Siswa kurang antusias terhadap permasalahan yang diberikan oleh guru.

3. Siswa kurang aktif berinteraksi dalam kelompok.

4. Siswa masih belum memahami peran pemonitor dalam kerja kelompok, sehingga membuat suasana kelas menjadi ribut.

5. Siswa kurang antusias menggunakan kupon berbicara yang diberikan karena masih bingung menggunakannya.

6. Siswa kurang terlatih menanggapi/ menjawab pertanyaan dan menyampaikan pendapat.

7. Siswa jarang sekali mengajukan pertanyaan terhadap guru (siswa cenderung pasif).

Adapun hasil observasi terhadap aktivitas guru selama pembelajaran berlangsung pada siklus I secara keseluruhan aktivitas guru masih terdapat kekurangan-kekurangan atau guru mengajar belum optimal. Adapun kekurangankekurangan yang dilakukan oleh guru pada saat proses belajar mengajar berlangsung adalah :

1. Guru belum optimal dalam menjelaskan tentang penggunaan kupon berbicara dan peran pemonitor sehingga membuat siswa jadi memiliki pendapat berbeda-beda dalam menggunakan kupon

2. Guru kurang membimbing dan mengontrol kegiatan siswa berdiskusi dalam kelompok dan dalam mendiskusikan jawaban pertanyaan sehingga waktu diskusi siswa banyak yang ribut.

3. Guru kurang mengalokasikan waktu dalam setiap kegiatan sehingga semua kegiatan dalam proses KBM yang direncanakan belum dapat terlaksana dengan baik.

\section{Refleksi I}

Berdasarkan hasil belajar siswa serta lembar observasi siswa maupun guru, pelaksanaan siklus I dikatakan belum berhasil dan perlu ditingkatkan pada siklus II. Ketidak berhasilan ini dapat dilihat dari rendahnya nilai siswa dan keaktifan. Selain itu perolehan hasil belajar siswa yang telah berhasil dalam belajar secara klasikal juga rendah. Ini disebabkan kerena kendala yang dihadapi oleh guru dan siswa dalam proses belajar mengajar.

Berdasarkan observasi pembelajaran IPA dengan menggunakan pembelajaran kooperatif time token, memperlihatkan adanya kekurangankekurangan dalam kegiatan belajar mengajar, diantaranya:

1. Siswa kurang memperhatikan waktu guru menerangkan tentang penggunaan kupon untuk berbicara dan peran pemonitor, hal ini disebabkan karena belum optimalnya guru menjelaskan tentang penggunaanya. 
2. Guru kurang mengontrol dan membimbing siswa pada saat diskusi kelompok sehingga keaktifan siswa untuk berbicara dalam kelompok belum berjalan dengan baik sehingga siswa banyak yang ribut.

3. Siswa jarang sekali mengajukan pertanyaan dan belum terlatih untuk menanggapi / menjawab pertanyaan dan dalam menyampaikan pendapat yang menyebabkan suasana kelas menjadi pasif.

4. Guru kurang mengalokasikan waktu dalam setiap kegiatan sehingga semua kegiatan yang direncanakan belum dapat terlaksana dengan baik.

Untuk memperbaiki kekurangan-kekurangan yang ada pada siklus I dan untuk meningkatkan hasil belajar siswa pada siklus II, maka perlu diperbaiki pada kegiatan pengajaran selanjutnya antara lain :

1. Mempertahankan hal-hal yang baik pada siklus I

2. Guru hendaknya lebih jelas dalam menjelaskan tentang pengunaan kupon berbicara dan tugas dari pemonitor sehingga siswa dapat tertarik dan terlibat dalam pembelajaran kooperatif yang dilaksanakan.

3. Guru sebaiknya mengontrol kegiatan siswa berdiskusi dalam kelompok dan memberikan teguran pada siswa yang ribut serta membimbing siswa dalam diskusi kelompok secara merata, sehingga waktu pelaksanaan diskusi terjadi interaksi antara siswa dengan siswa dan interaksi siswa dengan guru.

4. Guru sebaiknya memancing siswa untuk bertanya dan melatih siswa untuk menanggapi / menjawab pertanyaan dan menyampaikan pendapat dengan memberikan umpan pertanyaan dan umpan menjawab.

5. Sebelum pembelajaran IPA, sebaiknya guru mengalokasikan waktu untuk setiap kegiatan, agar semua kegiatan dalam proses KBM yang direncanakan dapat terlaksana semua.

\section{Siklus II}

\section{Perencanaan}

Pada tahap perencanaan, peneliti mempersiapkan perangkat pembelajaran, seperti RPP, LKS, alat dan bahan praktikum, kupon (kartu kecil), serta soal tes siklus II.

\section{Pelaksanaan Tindakan}

Berdasarkan hasil refleksi siklus I dilaksanakan perbaikan tindakan pada siklus II dengan langkah-langkah yang dilakukan pada tiap pertemuan sama seperti siklus I. Tindakan yang dilaksanakan pada siklus II dibagi dalam 3 kali pertemuan, pertemuan pertama mengenai materi pemantulan pada cermin cekung dan cermin cembung, pertemuan kedua membahas mengenai pembiasan cahaya dan indeks bias. Untuk meningkatkan perhatian siswa, maka pada waktu membuka pelajaran dan saat memotivasi siswa, guru melakukan kegiatan yang dapat menarik perhatian siswa dengan mengadakan demonstrasi atau memberikan informasi-informasi nyata yang berada disekitar siswa berkaitan dengan materi yang akan dibahas, sehingga siswa akan lebih mudah mengenal permasalahan yang akan dipecahkan.

Pada saat siswa bekerja dalam kelompoknya, tindakan yang dilakukan adalah membimbing, mengontrol, membantu dan mengarahkan kegiatan siswa. Pengarahan diberikan kepada siswa atau kelompok yang masih kurang memahami 
fungsi kupon berbicara, fungsi pemonitor dan permasalahan yang akan dibahas, sehingga siswa akan tetap terpusat pada kegiatan pembelajaran. Untuk mengetahui penguasaan siswa pada materi yang telah diajarkan pada siklus II maka dilaksanakan tes formatif II, dengan jumlah soal 10 soal pilihan ganda. Materi yang diujikan adalah materi yang dipelajari pada siklus II.

\section{Hasil belajar}

Hasil yang diperoleh siswa dari formatif 2 dapat dilihat pada tabel berikut:

Tabel 4 Hasil belajar siklus II yang diikuti oleh 22 orang siswa

\begin{tabular}{|c|l|c|}
\hline No & \multicolumn{1}{|c|}{ Variabel yang diamati } & Jumlah/persentase \\
\hline 1 & Nilai rata-rata siswa & $7,27(72,7 \%)$ \\
2 & Jumlah siswa yang berhasil & 14 orang \\
\hline
\end{tabular}

Dari tabel diketahui bahwa pelaksanaan tindakan pada siklus II sudah mengalami peningkatan dari siklus I. ini dapat diketahui dari hasil belajar siklus II yang telah diikuti oleh 22 siswa. Nilai rata-rata yang diperoleh meningkat dari $6,50 \%$ pada siklus I menjadi 7,27 pada siklus II. Dan jumlah siswa memperolah nilai $\geq 7,5$ sebanyak 14 orang, ini berarti keberhasilan klasikal telah mencapai $63,6 \%$. Sedangkan siswa yang belum berhasil $36,4 \%$ maka tindakan dilakukan pada siklus III.

\section{Hasil Observasi}

Berdasarkan hasil observasi yang merupakan gambaran aktivitas siswa selama proses pembelajaran berlangsung. Secara keseluruhan aktivitas siswa dalam menerapkan pembelajaran kooperatif sudah mengalami peningkatan dari siklus I aktivitas siswa dalam proses belajar sudah mengalami peningkatan apabila dibandingkan dengan aktivitas pada siklus I. hal ini dapat terlihat dari siswa yang siap untuk belajar IPA 16 orang $(72,7 \%)$, siswa termotivasi untuk belajar 15 orang $(68,2 \%)$, siswa memperhatihan sewaktu guru menyampaikan tujuan pembelajaran 15 orang $(68,2 \%)$, siswa memperhatikan sewaktu guru menyampaikan materi pelajaran 15 orang $(68,2 \%)$, siswa antusias terhadap permasalahan yang diberikan oleh guru 17 orang $(77,3 \%)$, siswa berinteraksi dalam kelompok 16 orang $(72,7 \%)$, siswa bekerjasama mengerjakan tugas kelompok dengan diawasi oleh pemonitor 20 orang $(90,9 \%)$, siswa menyampaikan jawaban kelompoknya 5 orang $(22,7 \%)$. Namun masih ada yang belum begitu meningkat yaitu keterampilan siswa memanfaatkan poin waktu yang diberikan 14 orang $(63,6 \%)$, keantusiasan siswa memanfaatkan poin waktu yang diberikan guru 12 orang $(54,5 \%)$, siswa menanggapi jawaban kelompok lain 4 orang $(18,2 \%)$, siswa bertanya tentang hal yang belum dimengerti hanya 2 orang (9\%), siswa ikut serta dalam merangkum materi pelajaran 3 orang $(13,6 \%)$ dan siswa yang mengerjakan latihan sesuai dengan waktu yang diberikan 15 orang $(68,2 \%)$. Ini menunjukkan bahwa keaktivan siswa dalam belajar semakin meningkat dan upaya meningkatkan hasil belajar siswa dapat terlaksana walaupun belum memuaskan.

Adapun hasil observasi terhadap aktivitas guru selama pembelajaran berlangsung pada siklus Isudah mengalami peningkatan apabila dibandingkan dengan hasil observasi tindakan silkus I. Namun masih ada hal-hal yang perlu 
diperbaiki lagi yaitu keterlibatan guru dalam diskusi kelas dan keterlibatan guru pada saat pembelajaran sangat dominan. Sedangkan pada saat pembelajaran kooperatif ini berlangsung lebih menekankan peran serta siswa bukan guru.

\section{Refleksi II}

Berdasarkan hasil belajar siswa serta lembar observasi siswa maupun guru, pelaksanaan siklus II sudah mengalami peningkatan dari siklus I. Ini dapat dilihat dari peningkatan belajar siswa pada tes formatif akhir siklus serta dari lembar observasi siswa dalam proses belajar mengajar. Tetapi pemberian tindakan masih perlu dilanjutkan dan diharapkan pada siklus III terjadi peningkatan yang lebih baik lagi, baik itu hasil belajar maupun keaktivan siswa.

Adapun kegiatan yang harus ditingkatkan oleh siswa dan guru pada siklus berikutnya berdasarkan hasil observasi siklus II antara lain :

1. Kegiatan siswa yang harus ditingkatkan berdasarkan hasil observasi siswa pada siklus II yaitu indikator no. 10, 11, 13, 14, 15 dan 16

2. Kegiatan guru yang harus ditingkatkan berdasarkan hasil observasi guru siklus II yaitu indikator no. 2, 13, 14, 15, 16, 17, 18, 20 dan 21.

3. Mempertahankan hal-hal yang baik pada siklus II

Selain itu ada beberapa hal yang perlu diperbaiki pada kegiatan pengajaran selanjutnya antara lain:

1. Guru hendaknya lebih menekankan fungsi dari kupon berbicara sehingga siswa terampil dan antusias dalam memanfaatkan poin waktu yang diberikan.

2. Guru sebaiknya mengontrol kegiatan siswa pada saat diskusi kelompok dengan dibantu pemonitor, sehingga semua siswa dapat berbicara sesuai dengan lama waktu yang diberikan dalam kupon dan dapat memberikan kesempatan kepada yang belum berbicara untuk mengungkapkan pendapatnya.

3. Guru memotivasi siswa untuk menanggapi jawaban dari kelompok lain dengan memberikan nilai lebih bagi yang bertanya ataupun yang memberikan masukan dan mengevaluasi kerja tiap-tiap kelompok.

4. Guru meminta siswa untuk menarik kesimpulan dari materi yang didiskusikan dengan menekankan poin-poin yang penting dari materi yang dipelajari.

5. Guru memotivasi siswa untuk bertanya dengan bertanya terlebih dahulu kepada siswa.

6. Guru memberikan sanksi kepada siswa yang tidak mengumpulkan tugas tepat pada waktunya dengan memberikan tugas tambahan.

\section{Siklus III}

\section{Perencanaan}

Pada tahap perencanaan, peneliti mempersiapkan perangkat pembelajaran, seperti RPP, LKS, alat dan bahan praktikum, kupon (kartu kecil), serta soal tes siklus III.

\section{Pelaksanaan tindakan}

Siklus III ini terdiri dari 2 rencana pembelajaran dengan materi pembiasan pada lensa cembung dan lensa cekung. Siklus III merupakan lanjutan dan 
perbaikan siklus-siklus sebelumnya. Proses pembelajaran yang dilakukan berdasarkan hasil refleksi tindakan pada siklus II, dimana masih terdapat beberapa kegiatan yang belum terlaksana dengan baik.

Adapun perbaikan yang harus dilakukan pada siklus III ini adalah guru hendaknya lebih menekankan fungsi dari kupon berbicara sehingga siswa terampil dan antusias dalam memanfaatkan poin waktu yang diberikan dan guru sebaiknya mengontrol kegiatan siswa pada saat diskusi kelompok dengan dibantu pemonitor, sehingga semua siswa dapat berbicara sesuai dengan lama waktu yang diberikan dalam kupon dan dapan memberikan kesempatan kepada yang belum berbicara untuk mengemukakan pendapatnya. Guru hedaknya memberikan kesempatan yang seluas-luasnya pada siswa untuk mengembangkan ketrampilan mereka, siswa dilatih untuk menggunakan ide, pendapat, mengajukan pertanyaan, menanggapi / menjawab pertanyaan atau dalam menarik kesimpulan. Jadi dalam hal ini guru hanya bertugas sebagai fasilitator, pembimbing dan menciptakan situasi/kondisi yang dapat membuat siswa terlibat secara aktif selama proses pembelajaran berlangsung. Untuk mengetahui tingkat penguasaan materi pada siklus III, maka dilakukan tes formatif 3 dengan jumlah soal 10 soal pilihan ganda. Materi yang diujikan adalah materi yang diajarkan pada siklus III.

\section{Hasil Belajar} berikut:

Hasil yang diperoleh siswa dari tes formatif III dapat dilihat pada tabel

Tabel 5. Hasil belajar siklus III yang diikuti oleh 22 orang siswa

\begin{tabular}{|c|l|c|}
\hline No & \multicolumn{1}{|c|}{ Variable yang diamati } & Jumlah/persentase \\
\hline 1 & Nilai rata-rata siswa & $8,36(83,6 \%)$ \\
2 & Jumlah siswa yng berhasil & 19 orang \\
\hline
\end{tabular}

Dari tabel diketahui bahwa pelaksanaan tindakan pada siklus III sudah mengalami peningkatan sesuai dengan yang diharapkan. Hal ini terlihar dari hasil belajar siklus III yang diikuti oleh 22 orang siswa. Nilai rata-rata yang diperoleh meningkat dari 7,27 \% pada siklus II menjadi 8,36 \% pada siklus III. Dan jumlah siswa memperoleh nilai $\geq 7,5$ sebanyak 19 orang, ini berarti keberhasilan klasikal telah mencapai $86,4 \%$.

\section{Hasil Observasi}

Berdasarkan hasil observasi yang merupakan gambaran aktivitas siswa selama proses pembelajaran berlangsung. Secara keseluruhan aktivitas siswa dalam menggunakan kupon berbicara sudah mengalami peningkatan dari siklus II, aktivitas siswa dalam proses belajar sudah mengalami peningkatan apabila dibandingkan dengan aktivitas pada siklus II. Siswa sudah berani dalam mengajukan dan menjawab pertanyaan, persentase keaktivan siswa dalam pelaksanaan KBM meningkat dari siklus sebelumnya. Sebagian besar siswa telah mengikuti jalannya pelaksanaan KBM secara tertib. Siswa terampil dan antusias dalam memanfaatkan poin waktu yang diberikan.

Adapun hasil observasi terhadap aktivitas guru selama pembelajaran berlangsung pada siklus III 
terlihat bahwa keterlibatan guru pada saat pembelajaran berlangsung sudah tidak mendominasi lagi. Siswa sudah lebih banyak berperan aktif dalam setiap kegiatan pembelajaran. Guru juga telah melaksanakan langkah-langkah dalam pengajaran sesuai dengan rencana pembelajaran.

\section{Refleksi III}

Berdasarkan hasil evaluasi yang diadakan melalui ulangan formatif 3, hasil belajar yang diperoleh siswa telah mengalami peningkatan yang sesuai dengan yang diharapkan. Berdasarkan analisa terhadap hasil ulangan formatif dan data observasi siklus III dapat diketahui bahwa tindakan yang dilakukan pada siklus ini telah berhasil meningkatkan hasil belajar siswa. Hal ini terlihat pada hasil belajar siswa yang telah memenuhi kriteria keberhasilan yang telah ditetapkan. Dari hasil tes diperoleh nilai rata-rata kelas 8,36 dan siswa yang memperoleh nilai $\geq 7,5$ sebanyak 19 orang atau 86,4 \% dari jumlah siswa secara keseluruhan yang telah mengalami keberhasilan belajar.

\section{Pembahasan}

Keberhasilan siswa dalam proses pembelajaran dipengaruhi oleh banyak faktor. Namun faktor yang paling utama adalah guru, materi pelajaran dan siswa itu sendiri. Agar proses belajar mengajar berjalan dengan baik dan dapat menghasilkan hasil yang optimal, maka diperlukan kerjasama yang baik antara ketiga faktor utama tadi. Kerjasama yang baik disini maksudnya adalah guru sebagai pengajar diharapkan mampu menanamkan konsep-konsep yang benar dan menerapkan metode penyajian yang tepat. Kurangnya variasi dalam kegiatan pembelajaran yang ditetapkan oleh guru menyebabkan siswa kurang berminat dalam mengikuti pembelajaran sehingga hasil belajar yang diperoleh siswa rendah. Untuk mengatasi permasalahan tersebut maka diterapkan suatu pembelajaran kooperatif dengan menggunakan kupon berbicara.

Tabel 6. Peningkatan hasil belajar siswa

\begin{tabular}{|c|l|c|c|c|}
\hline \multirow{2}{*}{ No } & \multicolumn{1}{|c|}{ Variabel yang diamati } & \multicolumn{3}{|c|}{ Jumlah/persentase } \\
\cline { 3 - 5 } & & Siklus I & Siklus II & Siklus III \\
\hline 1. & Nilai rata-rata kelas & $65,0 \%$ & $72,7 \%$ & $83,6 \%$ \\
2. & Jumlah siswa yang berhasil & 9 Orang & 14 Orang & 19 Orang \\
\hline
\end{tabular}

Dari tabel dapat diketahui bahwa terjadi peningkatan pada setiap siklusnya. Pada siklus I, dari ujian tes formatif didapatkan nilai rata-rata siswa 6,50\% dengan keberhasilan klasikal 9 orang (40,9\%), pada siklus II, nilai rata-rata siswa 7,27 dengan keberhasilan klasikal 14 orang $(63,6 \%)$ dan pada siklus III nilai ratarata siswa mencapai 8,36 \% dengan keberhasilan klasikal 19 orang $(86,4 \%)$. Hasil belajar siswa dari siklus I sampai siklus III mengalami peningkatan karena siswa lebih memahami materi dengan menggunakan pembelajaran kooperatif time token. Tipe ini menghendaki siswa aktif dalam mencari dan mengemukakan pendapat mengenai suatu masalah. Karena mencari sendiri jawaban dari masalah yang diberikan, siswa lebih mudah memahami dan mengingat materi yang diberikan.

Tingkat keaktifan siswa mengalami peningkatan pada setiap siklusnya. Siswa yang memperhatikan sewaktu guru menyampaikan materi pelajaran 
meningkat dari 14 orang $(63,6 \%)$ menjadi 15 orang $(68,2 \%)$ dan pada siklus III menjadi 19 orang $(86,4 \%)$. Siswa yang antusias terhadap permasalahan yang diberikan guru juga mengalami peningkatan dari 16 orang $(72,7 \%)$ menjadi 17 orang $(77,3 \%)$ dan pada siklus III 20 orang $(90,9 \%)$. Siswa yang berinteraksi dalam kelompok mengalami peningkatan dari 12 orang $(54,5 \%)$ menjadi 16 orang $(72,7 \%)$ dan pada siklus III menjadi 22 orang (100\%). Siswa yang bekerjasama mengerjakan tugas kelompok dengan diawasi pemonitor meningkat dari 20 orang (90,9\%) menjadi 22 orang (100\%) pada siklus III. Siswa yang terampil memanfaatkan poin waktu yang diberikan guru meningkat dari 10 orang $(45,5 \%)$ menjadi 14 orang $(63,6 \%)$ dan pada siklus III menjadi 20 orang $(90,9 \%)$. Siswa yang antusias memanfaatkan poin waktu yang diberikan guru juga mengalami peningkatan dari 8 orang $(36,4 \%)$ menjadi 12 orang $(54,5 \%)$ dan pada akhir siklus menjadi 19 orang $(86,4 \%)$. Aktivitas siswa mengalami peningkatan dari siklus I sampai siklus III karena siswa lebih termotivasi untuk belajar dengan menggunakan pembelajaran kooperatif time token. Tipe ini mengharuskan semua anggota kelompok terlibat aktif dalam pembelajaran, siswa merasa dihargai karena memiliki waktu yang sama mengemukakan ide, pendapat dan masukannya mengenai suatu masalah sehingga siswa dapat lebih aktif dalam pembelajaran.

Pada tingkat keaktivan guru, terjadi peningkatan pada setiap siklusnya. Pada siklus I yang termasuk kategori tidak melakukan ada 1 poin yaitu indikator no 2 karena pada siklus I guru belum mengumpulkan tugas melainkan memberikan tugas, yang termasuk kategori kurang ada 5 poin yaitu indikator no 13, 14, 18, 21 dan 23, yang termasuk kategori cukup ada 13 poin yaitu indikator no 3, 4, 5, 6, 7, $8,9,12,15,16,17,20$ dan 22 , yang termasuk kategori baik ada 4 poin yaitu indikator no 13, 14 dan 21 menjadi cukup, kategori kurang dari indikator no 18 dan 23 menjadi baik. Kategori cukup dari indikator no 3, 15, 16,17 dan 20 tetap cukup karena siswa masih sulit untuk diajak bekerjasama sehingga guru masih sulit untuk mengatur waktu dalam pembelajaran, kategori cukup dari indikator no 4, 5, 6, 7, 8, 9, 12 dan 22 mejadi baik, indikator no 1, 10, 11 dan 19 tetap dipertahankan dalam kategori baik. Sedangkan pada siklus III semua indikator meningkat menjadi baik semua kecuali indikator no 12 dari baik menjadi baik sekali. Peningkatan aktivitas guru pada setiap siklusnya dikarenakan guru sudah terbiasa menggunakan pembelajaran kooperatif time token dalam pembelajaran, sehingga rencana pembelajaran yang sudah dibuat dapat terlaksana dengan baik.

\section{Kesimpulan}

Hasil belajar IPA siswa dapat di tingkatkan melalui pembelajaran kooperatif tipe time token pada materi cahaya di kelas VIII ${ }^{\mathrm{C}}$ SMP N 7 Batanghari. Hal ini dapat di lihat dari peningkatan hasil belajar yang didapat oleh siswa pada setiap siklusnya, yaitu: 6, 50 pada siklus I, 7,27 pada siklus II dan 8,36 pada siklus III.

\section{Saran}

Diharapkan kepada guru supaya dapat menggunakan pembelajaran kooperatif tipe time token sebagai alternatif dalam pembelajaran, khususnya guru IPA.

\section{Daftar Rujukan}


Arends, Richard I. 2008. Learning to tearch. Terj. Helly Prajitno Soetjipto dan Si Mulyantini Soetjipto. Yogyakarta: Pustaka Pelajar.

Arikunto, dkk. 2012. Penelitian Tindakan Kelas. Jakarta: Bumi Aksara.

Aqib, Zainal. 2013. Model-model, Media dan Strategi Pembelajaran Kontekstual (Inovatif). Bandung: Yrama Widya.

Fitriani. 2005. Peningkatan Kualitas Pembelajaran Fisika Melalui Penerapan Cooperative Learning Dalam Bentuk make a macht Pada Siswa Kelas 1 SMP Negeri 4 Sawah Lunto. Padang: UNP.

Hamalik, Oemar. 2002. Psikologi Belajar dan Mengajar. Bandung: Sinar Baru.

Hartati. 2006. Peningkatan Hasil Belajar Pada Konsep Kelarutan dan Hasil Kali Kelarutan Melalui Pembelajaran Kooperatif Teams Games Tournaments kelas XI IPA Unggul SMA 4 Jambi. Jambi: Unja.

Ibrahim, M., dkk. 2000. Pembelajaran Kooperatif. Surabaya: University PressUNESA.

Mahfudz, Asep. 2012. Cara Cerdas Mendidik yang Menyenangkan. Bandung: Simbiosa Rekatama Media.

Noeraida, dkk. 2016. Teori Belajar dan Implementasinya Dalam Pembelajaran. Jakarta : Kemdikbud.

Rusman. 2012. Model-model Pembelajaran. Jakarta: Rajawali Pers.

Sardiman, A. 2001. Interaksi dan Motivasi Belajar Mengajar. Jakarta: PT Raja Grafindo Persada.

Sudjana, Nana. 1996. Cara Belajar Siswa Aktif dalam Proses Belajar Mengajar. Bandung: Sinar Baru Algensindo.

Trianto. 2010. Mendesain Model Pembelajaran Inovatif-Progresif. Jakarta: Kecana Prenada Media Grup. 
Desma Yetti

42 Annaba : Jurnal Pendidikan Islam 